\title{
TOTAL QUALITY MANAJEMENT (TQM) \\ SEBAGAI MANAJEMEN MUTU ALTERNATIF PADA PROGRAM STUDI PENDIDIKAN BAHASA ARAB
}

\author{
Syarifuddin ${ }^{1}$
}

\begin{abstract}
Abstrak
Total Quality Manajement (TQM), yang pada mulanya adalah salah satu manajemen mutu yang diterapkan di perusahaan, merupakan suatu pendekatan sistematis dan hati-hati untuk mencapai tingkatan kualitas yang tepat dengan cara yang konsisten dalam memenuhi kebutuhan dan keinginan pelanggan. Program studi Pendidikan Bahasa Arab (prodi PBA) memerlukan suatu manajemen mutu pendidikan yang menjamin pelanggan atau stake holdernya 'puas'. Tulisan ini menawarkan TQM sebagai alternatif manajemen mutu yang bisa diterapkan di prodi PBA. TQM mempunyai empat unsur pokok yang bisa ditemukan dan diterapkan juga pada prodi PBA yaitu: pelanggan, respek terhadap setiap orang, manajemen berdasarkan fakta, dan perbaikan berkesinambungan. TQM juga mempunyai dua standar mutu yang bisa diimplementasikan pada prodi PBA yaitu (1) standar produk atau jasa (quality in fact), yaitu: kesesuain dengan spesifikasi; keseuaian dengan tujuan dan manfaat; tanpa cacat (zero defects); dan selalu baik sejak awal, dan (2) standar Pelanggan (quality in perception), yaitu: kepuasan pelanggan; memenuhi kebutuhan pelanggan; dan menyenangkan pelanggan.
\end{abstract}

Kata Kunci: Manajemen Mutu, Total Quality Manajement (TQM),

Program Studi Pendidikan Bahasa Arab (PBA)

\section{A. Pendahuluan}

Seiring dengan makin lebarnya ruang pendidikan, diindikasikan akan ada pergeseran pandangan atau paradigma dari pengelolaan suatu institusi yang konvensional ke pengelolaan yang mempunyai manajemen handal. Lembaga atau institusi tidak hanya cukup membekali peserta didiknnya dengan ijazah tanpa memperhatikan kualitas atau mutu peserta didiknya.

Tuntutan perubahan telah memaksa paradigma pendidikan secara perlahan bergeser ke arah yang lebih professional. Hal ini ditandai dengan gejala seperti: kekuatan symbol (ijazah) akan bergeser ke kekuatan kemampuan performa; kekuatan individu akan bergeser ke kekuatan jaringan; kekuatan formal akan bergeser ke daya pengaruh; system evaluasi belajar yang hanya mengukur hafalan dan daya ingat akan bergeser ke evaluasi kemampuan total; persaingan akan bergeser dari harga ke layanan atau kualitas, dan seterusnya (Mulyasana, 2011 : 23).

Dari fenomena pergeseran paradigma pendidikan di atas, institusi atau lembaga pendidikan memerlukan suatu manajemen mutu pendidikan yang menjamin pelanggan atau stake holdernya 'puas'. Demikian halnya dengan program studi pendidikan Bahasa Arab (PBA) yang banyak ditemui hampir di seluruh universitas Islam, sekolah tinggi agama Islam, institut agama Islam dan bahkan di perguruan tinggi umum sekalipun, mereka dituntut untuk selalu mengupgrade manajemen mutu institusinya agar menghasilkan lulusan-lulusan yang bermutu atau berkualitas. Tentu banyaknya perguruan tinggi yang mempunyai prodi PBA akan memunculkan persaingan yang ketat dalam dunia kerja. Tulisan ini akan mencoba membahas sekelumit tentang

\footnotetext{
${ }^{1}$ Penulis adalah Dosen pada Universitas Yudharta Pasuruan.
} 
manajemen mutu dan Total Quality Management (Manajemen Mutu Terpadu) sebagai alternatif manajemen mutu pada prodi PBA.

\section{B. Manajemen Mutu dan Total Quality Management}

Dalam Kamus Besar Bahasa Indonesia Mutu atau kualitas adalah ukuran baik buruk suatu benda, kadar, taraf atau derajat berupa kepandaian, kecerdasan, kecakapan, dan sebagainya (Depdiknas, 1991 : 667). Menurut Crosby, mutu yaitu sesuai dengan yang disyaratkan atau distandarkan. Suatu produk memiliki kualitas apabila memiliki standar kualitas yang telah ditentukan. Deming berpendapat bahwa kualitas adalah kesesuaian dengan pasar. Kualitas sebagai kesesuaian dengan kebutuhan pasar dan konsumen. Sallis menjelaskan bahwa mutu atau kualitas adalah sesuatu yang memuaskan dan melampaui keinginan dan kebutuhan seseorang atau sekelompok orang (Edward, 2011).

Menurut Amtu (2011 : 120) mutu adalah layanan produk berupa barang atau jasa yang bertalian dengan pemenuhan kebutuhan, harapan dan harganya mampu dijangkau pelanggan. Mutu tidak sekedar pada barang atau jasa, melainkan pada aspek, estetika, kenyamanan, praktis, tahan lama, keramahtamahan (kesopanan) dalam pelayanan, ketepatan waktu, serta disesuaikan dengan harapan dan keinginan pelanggan baik pelanggan internal maupun eksternal. Mutu adalah sifat dari benda dan jasa yang nampak dan disarankan serta diyakini. Setiap orang selalumengharapkan bahkan menuntut mutu dari orang lain, sebaiknya orang lain juga selalu mengharapkan dan menuntut mutu dari kita. Mutu bukan juga dimengerti sebatas pada barang atau produk material, karena mutu juga secara lahiriah menyangkut kapasitas dan kompetensi seseorang. Ini artinya, mutu bukanlah sesuatu yang baru, karena mutu adalah naluri manusia untuk membedakan baik dan buruk.

Dengan demikian, mutu adalah panduan atau standardisasi sifat-sifat dari barang atau jasa, yang menunjukkan kemampuannya dalam memenuhi kebutuhan pelanggan, baik kebutuhan langsung maupun tidak langsung atau yang dinyatakan maupun yang tersirat. Mutu atau kualitas tidak bergantung pada tinggi-rendahnya harga penjualan, melainkan pada kepuasan pelanggan. Pelanggan adalah pemakai produk dan jasa layanan yang menilai seberapa jauh kualitas barang atau jasa yang dinikmati memberikan harapan dan menjawab kebutuhannya. Jika pelanggan mengungkapkan kepuasannya atas suatu produk atau jasa, maka dengan sendirinya muncul keinginan yang kuat untuk terus menggunakan produk atau jasa dimaksud sekalipun mahal harganya.

Keunggulan mutu tidak sebatas pada areal/wilayah bisnis dan industri, tetapi jika diterapkan didunia pendidikan, maka akan berdampak positif baik bagi siswa atau mahasiswa, guru atau dosen, maupun orang tua dan masyarakat. Singkatnya, mutu adalah suatu konsep dan aplikasi mengenai standardisasi kebutuhan-kebutuhan formal manusia berkaitan dengan aspek kemanusiaan dan sumber daya yang dimilikinya. Konsep mutu atau kualitas sangat bergantung pada sudut pandang setiap orang. Diantara para pakar kualitas/mutu masih terdapat perbedaan pandangan, sekalipun pada segi-segi tertentu, terdapat persamaan diantara mereka. Namun, penekanannya terutama pada bagaimana meningkatkan kualitas baik pada produk barang maupun layanan jasa, melalui manajemen yang professional dan berkesinambungan. Jadi, definisi mutu atau kualitas yang tepat sangat bergantung pada pesepsi pelanggan. Karena pelanggan yang memutuskan suatu produk barang atau layanan jasa yang diterima, baik atau buruk, maka sekalipun pengertian kualitas terkesan relatif, namun secara umum, mutu atau kualitas berarti keterperluan harapan dan kepuasan seseorang yang menggunakan produk baik berupa barang atau jasa layanan yang benar-benar meyakinkan dan memuaskan. Kualitas atau mutu tidak merasa puas jika menggunakan 
suatu produk atau jasa, maka pelanggan dimaksud akan tetap menggunakannya (Amtu, $2011:$ 121).

Untuk mempermudah pemahaman mengenai berbagai pendapat mutu yang dikemukakan para ahli, maka berikut disajikan pengertian mutu menurut Edward Deming, Joseph Juran, dan Philip Crosby sebagai berikut (Nasution, 20015 : 40-41).

Tabel Perbandingan Pandangan Mutu atau Kualitas

\begin{tabular}{|c|c|c|c|c|}
\hline No & Konsep & Edward Deming & Joseph Juran & Philip Crosby \\
\hline 1. & $\begin{array}{l}\text { Definisi Mutu atau } \\
\text { Kualitas }\end{array}$ & $\begin{array}{l}\text { Suatu tingkat yang dapat } \\
\text { diprediksi dari } \\
\text { keseragaman dan } \\
\text { ketergantungan pada } \\
\text { biaya yang rendah dan } \\
\text { sesuai dengan pasar. }\end{array}$ & $\begin{array}{l}\text { Kemampuan untuk } \\
\text { digunakan (fitness for } \\
\text { use). }\end{array}$ & $\begin{array}{l}\text { Sesuai dengan } \\
\text { persyaratan }\end{array}$ \\
\hline 2. & $\begin{array}{l}\text { Tingkat Tanggung } \\
\text { Jawab Manajemen } \\
\text { Senior }\end{array}$ & $\begin{array}{l}\text { Bertanggung jawab } 94 \% \\
\text { atas masalah kualitas. }\end{array}$ & $\begin{array}{l}\text { Kurang dari } 20 \% \\
\text { masalah kualitas } \\
\text { karena pekerja. }\end{array}$ & $\begin{array}{l}\text { Bertanggungjawa } \\
\text { b untuk kualitas. }\end{array}$ \\
\hline 3. & $\begin{array}{l}\text { Standar } \\
\text { Prestasi/Motivasi }\end{array}$ & $\begin{array}{l}\text { Kualitas memiliki banyak } \\
\text { skala sehingga perlu } \\
\text { digunakan statistic untuk } \\
\text { mengukur prestasi pada } \\
\text { semua bidang; kerusakan } \\
\text { nol sangat penting. }\end{array}$ & $\begin{array}{l}\text { Menghindari } \\
\text { kampanye untuk } \\
\text { melakukan pekerjaan } \\
\text { yang sempurna. }\end{array}$ & $\begin{array}{l}\text { Kerusakan nol } \\
\text { (zero defect) }\end{array}$ \\
\hline 4. & Pendekatan Umum & $\begin{array}{l}\text { Mengurangi } \\
\text { keanekaragaman dengan } \\
\text { perbaikan } \\
\text { berkesinambungan dan } \\
\text { menghentikan inspeksi } \\
\text { massal. }\end{array}$ & $\begin{array}{l}\text { Pendekatan } \\
\text { manajemen umum } \\
\text { terhadap kualitas, } \\
\text { khususnya unsure } \\
\text { manusia. }\end{array}$ & $\begin{array}{l}\text { Pencegahan, } \\
\text { bukanlah } \\
\text { inspeksi. }\end{array}$ \\
\hline 5. & Struktur & $\begin{array}{l}14 \text { butir untuk } \\
\text { manajemen. }\end{array}$ & $\begin{array}{l}10 \text { butir perbaikan } \\
\text { kualitas. }\end{array}$ & $\begin{array}{l}14 \text { langkah } \\
\text { perbaikan } \\
\text { kualitas. }\end{array}$ \\
\hline 6. & $\begin{array}{l}\text { Pengendalian Proses } \\
\text { Statistik }\end{array}$ & $\begin{array}{l}\text { Metode statistik untuk } \\
\text { pengendalian kualitas } \\
\text { harus digunakan. }\end{array}$ & $\begin{array}{l}\text { Merekomendasikan } \\
\text { SPC (statistical } \\
\text { process control) } \\
\text { tetapi mengingatkan } \\
\text { bahwa SPC dapat } \\
\text { mengakibatkan total } \\
\text { driven approach. }\end{array}$ & $\begin{array}{l}\text { Menolak tingkat } \\
\text { kualitas yang } \\
\text { dapat diterima } \\
\text { secara statistik. }\end{array}$ \\
\hline 7. & Basis Perbaikan & $\begin{array}{l}\text { Secara terus menerus } \\
\text { mengurangi } \\
\text { penyimpangan; } \\
\text { menghilangkan tujuan } \\
\text { tanpa metode. }\end{array}$ & $\begin{array}{l}\text { Pendekatan } \\
\text { kelompok proyek- } \\
\text { proyek; menetapkan } \\
\text { tujuan. }\end{array}$ & $\begin{array}{l}\text { Suatu proses, } \\
\text { bukanlah suatu } \\
\text { program, tujuan } \\
\text { perbaikan. }\end{array}$ \\
\hline 8. & Kerja Sama Tim & $\begin{array}{l}\text { Partisipasi karyawan } \\
\text { dalam pengambilan } \\
\text { keputusan dan } \\
\text { memecahkan kendala }\end{array}$ & $\begin{array}{l}\text { Pendekatan tim dan } \\
\text { gugus kendali mutu. }\end{array}$ & $\begin{array}{l}\text { Kelompok } \\
\text { perbaikan kualitas } \\
\text { dan dewan } \\
\text { kualitas. }\end{array}$ \\
\hline 9. & Biaya Kualitas & Tidak ada optimum & $\begin{array}{l}\text { Quality is not free, } \\
\text { terdapat suatu }\end{array}$ & $\begin{array}{l}\text { Cost of } \\
\text { nonconformance; }\end{array}$ \\
\hline
\end{tabular}




\begin{tabular}{|l|l|l|l|l|}
\hline & & perbaikan terus-menerus. & optimum. & quality is free. \\
\hline 10. & $\begin{array}{l}\text { Pembelian dan Barang } \\
\text { yang diterima }\end{array}$ & $\begin{array}{l}\text { Inspeksi terlalu } \\
\text { terlambat; Barang yang } \\
\text { diterima. }\end{array}$ & $\begin{array}{l}\text { Masalah pembelian } \\
\text { menggunakan tingkat } \\
\text { kualitas yang dapat } \\
\text { diterima. }\end{array}$ & $\begin{array}{l}\text { Nyatakan } \\
\text { persyaratan; } \\
\text { pemasok adalah } \\
\text { perluasan. }\end{array}$ \\
\hline 11. & Penilaian Pemasok & $\begin{array}{l}\text { Tidak, kritikal dari } \\
\text { kebanyakan system. }\end{array}$ & $\begin{array}{l}\text { Ya, tetapi membantu } \\
\text { pemasok } \\
\text { memperbaiki. }\end{array}$ & $\begin{array}{l}\text { pemasok adalah } \\
\text { perluasan. }\end{array}$ \\
\hline 12. & $\begin{array}{l}\text { Hanya Satu Sourcing } \\
\text { of Supply }\end{array}$ & Ya. & $\begin{array}{l}\text { Tidak, dapat } \\
\text { diabaikan untuk } \\
\text { meningkatkan daya } \\
\text { saing. }\end{array}$ & \\
\hline
\end{tabular}

Ada banyak standar mutu yang berkembang di dunia di antaranya standar mutu BS5750, ISO9000, BS7850, Investors in People, the Deming Prize, the Malcolm Baldridge Award, the European Quality Award, the Citizen's Charter, dan lain sebagainya. Namun dalam tulisan ini, penulis akan mengambil Total Quality Management (TQM) yang biasanya diterjemahkan menjadi Manajemen Mutu Terpadu.

Sebelum membahas lebih lanjut tentang Manajemen mutu terpadu atau total quality management (TQM), ada dua istilah yang muncul sebelumnya yaitu: control mutu (quality control) dan jaminan mutu (quality assurance). Kontrol mutu secara historis merupakan konsep yang paling tua yang melibatkan deteksi dan eliminasi komponenkomponen atau produk gagal yang tidak sesuai standar. Ini merupakan proses pasca produksi yang menolak item-item cacat. Jaminan mutu berbeda dengan control mutu, baik sebelum maupun ketika proses berlangsung. Penekanan ini bertujuan untuk mencegah terjadi kesalahan sejak awal proses produksi. Jaminan mutu adalah sebuah cara menghasikan produk atau jasa yang bebas dari cacat dan kesalahan (zero defects). Jaminan mutu adalah pemenuhan spesifikasi produk secara konsisten atau menghasilkan produk yang 'selalu baik sejak awal' (right first time every time) (Edward, 2011 : 58-59).

Manajemen mutu terpadu atau total quality management (TQM) merupakan perluasan dan pengembangan dari jaminan mutu. TQM adalah tentang usaha menciptakan sebuah kultur mutu yang mendorong semua anggota stafnya untuk memuaskan para pelanggan. Dalam konsep mutu terpadu pelanggan adalah raja (Amtu, $2011: 123$ )

TQM adalah sebuah konsep yang awalnya dikembangkan untuk meningkatkan mutu produksi berupa barang dan jasa pada sejumlah perusahaan di Jepang. Sekalipun pengembangan konsep TQM mulai diperkenalkan dalam dunia industri pasca perang dunia ke-II, namun gagasan dasarnya sudah jauh dikembangkan oleh Fredrick Taylor yang dikenal sebagai "Bapak Manajemen Ilmiah" di tahun 1920- an. Pasca perang dunia ke-II, semua Negara mengembangkan industrinya dengan menawarkan produk barang dan jasa secara besar-besaran. Sekalipun Amerika dan dunia Barat masih dianggap sebagai lokomotif perkembangan IPTEK dan industri yang berkembang pesat dan berkualitas, namun di kemudian hari mulai tersaingi dan bahkan tertinggal oleh industri-industri Jepang yang mengembangkan pemikiran Edward Deming, Joseph Juran dan selanjutnya Philip Crosby mengenai manajemen mutu terpadu (total quality management) sehingga mampu merebut pasar dalam dan luar negeri Jepang, termasuk Amerika Serikat dan Eropa (Amtu, $2011: 123$.

Pemahaman mengenai TQM yang secara serempak diberlakukan di semua industri Jepang, menggambarkan bahwa sekalipun Jepang kalah dalam perang dunia ke-II, 
namun mereka unggul dalam persaingan industri dan perdagangan. Belajar dari keberhasilan industri Jepang dalam penerapan TQM untuk meningkatkan mutu produksi baik berupa barang dan layanan jasa, maka beberapa model yang digunakan, mengacu pada gagasan-gagasan cemerlang yang dari para pakar kualitas, yaitu: Edwards Deming, Joseph Juran, dan Philip Crosby, sebagai berikut:

Deming, mengusulkan empat belas point (Nasution, 2005 : 33):

1. Ciptakan keajegan tujuan dalam menuju perbaikan produk oleh jasa, dengan maksud untuk menjadi lebih dapat bersaing, tetap berada dalam bisnis, dan untuk menciptakan lapangan kerja.

2. Adopsilah falsafah baru. Manajemen harus memahami adanya era ekonomi baru dan siap menghadapi tantangan, belajar bertanggungjawab dan mengambil alih kepemimpinan guna menghadapi perubahan.

3. Hentikan ketergantungan pada inspeksi dalam membentuk mutu produk. Bentuklah mutu sejak dari awal.

4. Hentikan praktik menghargai kontrak berdasarkan tawaran yang rendah.

5. Perbaiki secara konstan dan terus-menerus system produksi dan jasa, untuk meningkatkan kualitas dan produktifitas, yang pada gilirannya secara konstan menurunkan biaya.

6. Lembagakan on the job training (pelatihan kerja).

7. Lembagakan kepemimpinan. Tujuan dari kepemimpinan haruslah untuk membantu orang dan teknologi dapat bekerja dengan lebih baik.

8. Hapus rasa takut sehingga setiap orang dapar bekerja secara efektif .

9. Hilangkan dinding pemisah antar departemen sehingga orang dapat bekerja sebagai suatu tim.

10. Hilangkan slogan, desakan, dan target bagi tenaga kerja. Hal-hal tersebut dapat menciptakan permusuhan.

11. Hilangkan kuota dan menejemen berdasarkan sasaran. Gantikan dengan kepemimpinan.

12. Hilangkan penghalang yang dapat merampok kebanggaan karyawan atas keahliannya.

13. Giatkan program pendidikan dan self-improvement (perbaikan diri).

14. Buatlah transformasi pekerjaan setiap orang dan siapkan setiap orang untuk mengerjakannya.

Joseph Juran mengusulkan sepuluh langkah: (1) Membentuk kesadaran terhadap kebutuhan akan perbaikan dan peluang untuk melakukan perbaikan; (2) Menetapkan tujuan perbaikan; (3) Mengorganisasikan untuk mencapai tujuan yang telah ditetapkan; (4) Menyediakan pelatihan; (5) Melaksanakan proyek-proyek yang ditujukan untuk pemecahan masalah;(6) Melaporkan perkembangan; (7) Memberikan penghargaan; (8) Mengkomunikasikan hasil-hasil; (9) Menyimpan dan mempertahankan hasil yang dicapai; Dan (10) Memlihara momentum dengan melakukan perbaikan dalam system regular perusahaan (Edward, $2005: 107$-110).

Disamping mengusulkan sepuluh langkah, dikenal juga apa yang disebut sebagai Trilogi Juran, yaitu: Perencanaan kualitas, pengendalian kualitas, dan perbaikan kualitas.

1. Perencanaan Kualitas

Perencanaan kualitas meliputi pengembangan produk, system dan proses yang dibutuhkan untuk memenuhi atau melampaui harapan pelanggan. Langkah-langkah yang dibutuhkan adalah sebagai berikut:

a. Menentukan siapa yang menjadi pelanggan.

b. Mengidentifikasi kebutuhan pelanggan.

c. Mengembangkan produk dengan keistimewaan yang dapat memenuhi kebutuhan pelanggan. 
d. Mengembangkan system dan proses yang memungkinkan organisasi untuk menghasilkan keistimewaan tersebut.

e. Menyebarkan rencana kepada level operasional.

2. Pengendalian Kualitas

Pengendalian kualitas meliputi langkah-langkah berikut:

a. Menilai kinerja kualitas actual.

b. Membandingkan kinerja dengan tujuan.

c. Bertindak berdasarkan perbedaan antara kinerja dan tujuan.

3. Perbaikan Kualitas

Perbaikan kualitas harus dilakukan secara on-going dan terus-menerus. Langkahlangkah yang dapat dilakukan adalah:

a. Mengembangkan infrastruktur yang diperlukan untuk melakukan perbaikan kualitas setiap bulan.

b. Mengidentifikasi bagian-bagian yang membutuhkan perbaikan dan melakukan proyek perbaikan.

c. Membentuk suatu tim proyek yang bertanggungjawab dalam menyelesaikan setiap proyek.

d. Memberikan tim-tim tersebut apa yang mereka butuhkan agar dapat mendiagnosis masalah guna menentukan sumber penyebab utama, memberikan solusi, melakukan pengendalian yang akan mempertahankan keuntungan yang diperoleh.

Philip B. Crosby, dengan empat dalil dan empat belas langkah, yaitu: Dalil 1; definisi kualitas adalah sama dengan persyaratan, Dalil 2; system kualitas adalah pencegahan, Dalil 3; kerusakan nol (zero defect) merupakan standar kinerja yang harus digunakan, Dalil 4; ukuran kualitas adalah price of non conformating (harga dari ketidakseragaman). Disamping empat dalil diatas, Philip Crosby juga mengusulkan 14 langkah, meliputi: (Edward, $2005: 110-118$ )

1. Komitmen pada pimpinan. Inisiatif pencapaian mutu pada umumnya oleh pimpinan dan dikomunikasikan sebagai kebijakan secara jelas dan dimengerti oleh seluruh unsure pelaksana lembaga.

2. Bentuk tim perbaikan mutu yang bertugas merumuskan dan mengendalikan program peningkatan mutu.

3. Buatlah pengukuran mutu, dengan cara tentukan baseline data saat program peningkatan mutu dimuali, dan tentukan standar mutu yang diinginkan sebagai patokan. Dalam penentuan standar mutu libatkanlah pelanggan agar dapat diketahui harapan dan kebutuhan mereka.

4. Menghitung biaya mutu. Setiap mutu dari suatu produk/jasa dihitung termasuk di dalamnya antara lain: kalau terjadi pengulangan pekerjaan jika terjadi kesalahan, inspeksi/superfisi, dan test/percobaan.

5. Membangkitkan kesadaran akan mutu bagi setiap orang yang terlibat dalam proses produksi/jasa dalam lembaga.

6. Melakukan tindakan perbaikan. Untuk ini perlu metodologi yang sitematis agar tindakan yang dilakukan cocok dengan penyelesaian masalah yang dihadapi, dan karenanya erlu dibuat suatu seri tugas-tugas tim dalam agenda yang cermat. Selama pelaksanaan sebaiknya dilakukan pertemuan regular agar didapat feed back dari mereka.

7. Lakukan perencanaan kerja tanpa cacat (zero defect planning) dari pimpinan sampai pada seluruh staf pelaksana.

8. Adakan pelatihan pada tingkat pimpinan (supervisor training) untuk mengetahui peranan mereka masing-masing dalam proses pencapaian mutu, teristimewa bagi 
pimpinan tingkat menengah. Lebih lanjut juga bagi pimpinan tingkat bawah dan pelaksananya.

9. Adakan hari tanpa cacat, untuk menciptakan komitmen dan kesadaran tentang pentingnya pengembangan staf.

10. Goal Setting (penyusunan tujuan). Setiap tim/bagian merumuskan tujuan yang akan dicapai dengan tepat dan harus dapat diukur keberhasilannya.

11. Berusaha menghilangkan penyebab kesalahan. Ini berarti sekaligus melakukan usaha perbaikan. Salah satu dari usaha ini adalah adanya kesempatan staf mengkomunikasikan kepada atasannya mana diantara pekerjaannya yang sulit dilakukan.

12. Harus ada pengakuan atas prestasi (recognition) bukan berupa uang, tetapi misalnya penghargaan atau sertifikat dan lainnya sejenis.

13. Bentuk suatu Komisi Mutu, yang secara professional akan merencanakan usaha-usaha perbaikan mutu dan memonitor secara berkelanjutan, dan

14. Lakukan berulangkali, karena program mencapai mutu tidak pernah akan berakhir.

Sallis mendefinisikan TQM sebagai sebuah pendekatan praktis, namun strategis, dalam menjalankan roda organisasi yang memfokuskan diri pada kebutuhan pelanggan dan kliennya. Tujuannya adalah untuk mencari hasil yang lebih baik. TQM bukan merupakan sekumpulan slogan, namun merupakan suatu pendekatan sistematisdan hati-hati untuk mencapai tingkatan kualitas yang tepat dengan cara yang konsisten dalam memenuhi kebutuhan dan keinginan pelanggan. TQM dapat dipahami sebagai filosofi perbaikan tanpa henti hingga tujuan organisasi dapat dicapai dan dengan melibatkan segenap komponen dalam organisasi tersebut (Edward, 2005 : 76).

\section{Faktor-Faktor Penunjang dalam Peningkatan Mutu Pendidikan Bahasa Arab}

Untuk meningkatkan mutu pembelajaran bahasa Arab bisa mengadopsi dari Danim yaitu dengan melibatkan lima faktor yang dominan (Sudarwan, 2007 : 56).

1. Kepemimpinan ketua program studi; ketua prodi atau jurusan harus memiliki dan memahami visi kerja secara jelas, mampu dan mau bekerja keras, mempunyai dorongan kerja yang tinggi, tekun dan tabah dalam bekerja, memberikan layanan yang optimal, dan disiplin kerja yang kuat.

2. Mahasiswa; pendekatan yang harus dilakukan adalah "mahasiswa sebagai pusat " sehingga kompetensi dan kemampuan mahasiswa dapat digali sehingga prodi dapat menginventarisir kekuatan yang ada pada mahasiswa .

3. Dosen; pelibatan dosen secara maksimal, dengan meningkatkan kompetensi dan profesi kerja dosen dalam kegiatan seminar, lokakarya serta pelatihan sehingga hasil dari kegiatan tersebut diterapkan di prodi.

4. Kurikulum; adanya kurikulum yang tetap tetapi dinamis, dapat memungkinkan dan memudahkan standar mutu yang diharapkan sehingga goals (tujuan) dapat dicapai secara maksimal;

5. Jaringan Kerjasama; jaringan kerjasama tidak hanya terbatas pada lingkungan kampus dan masyarakat semata (orang tua dan masyarakat ) tetapi dengan organisasi lain, seperti instansi sehingga output dari prodi dapat terserap di dalam dunia kerja

Menurut Depdiknas (2003 : 10), di antara faktor-faktor penunjang peningkatan mutu pendidikan yang biasanya juga disebut dengan butur-butir mutu: (1) Kurikulum program studi; (2) Sumber daya manusia (dosen, dan tenaga penunjang); (3) Mahasiswa; (4) Proses pembelajaran; (5) Prasarana dan sarana; (6) Suasana akademik; (7) Keuangan; (8) Penelitian dan publikasi; (9) Pengabdian kepada masyarakat; (10) 
Tata pamong (governance); (11) Manajemen lembaga; (12) Sistem informasi; dan (13) Kerjasama dalam dan luar negeri.

Menurut Singgih dan Rahmayanti (2008 : 133-141) ada 10 faktor yang mempengaruhi kualitas pendidikan di perguruan tinggi yaitu (1) tata kelola, (2) pengabdian pada masyarakat, (3) kurikulum program studi, (4) proses pembelajaran, (5) sumber daya manusia, (6) suasana akademik, (7) penelitian dan publikasi, (8) kemahasiswaan, (9) keuangan, dan (10) prasarana dan sarana.

Menurut Universitas Gadja Mada (UGM), secara luas pengertian mutu pendidikan tinggi dapat mencakup aspek sarana/prasarana, organisasi, manajemen, masukan, proses, keluaran yang dapat memuaskan pelanggan internal (dosen, staf administrasi, pengelola universitas) serta pelanggan eksternal (mahasiswa, orang tua, masyarakat pengguna serta masyarakat yang lebih luas), dengan perincian sebagai berikut:

a. Unsur-unsur masukan antara lain:

1). Mahasiswa.

2). Dosen dan staf administrasi

3). Keuangan.

4) Sarana/Prasarana.

5). Informasi.

b. Unsur-unsur proses mencakup;

1). Prodi

2). Proses belajar mengajar dan evaluasi hasil belajar

3). Sistem manajemen

c. Unsur-unsur keluaran antara lain;

1). Lulusan

2). Penelitian

3). Pengabdian kepada masyarakat (UGM, $2003: 2$ ).

Indikator kinerja penyelenggara kegiatan akademik terdiri atas indikator-indikator yang antara lain :

a. Indikator Masukan:

1) Nilai ijazah calon mahasiswa: semakin tinggi nilai bahasa Arab di ijazah madrasah aliyah para mahasiswa, maka para mahasiswa akan semakin mudah dalam mengikuti proses pembelajaran di PBA. Dengan kata lain, prodi akan terbantu dengan 'bekal' para mahasiswa tersebut.

2) Nilai tes seleksi mahasiswa baru: Semakin banyak peminat PBA dari kuota yang ada, maka mahasiswa yang tersaring akan semakin bagus.

3) Jumlah dan kompetensi dosen: Jumlah dosen PBA dengan rasio 1 dosen PBA membimbing 10 mahasiswa adalah ukuran standar. Adapun mengenai kompetensi, Depdiknas mensyaratkan dosen S-1 Prodi PBA harus minimal lulusan magister S-2 linier (S-1 dan S-2 Pendidikan Bahasa Arab). Lebih lengkapnya dosen harus memiliki kompetensi pedagogik, kepribadian, sosial, dan professional.

b. Indikator Proses:

1) Kesesuaian proses dengan kerangka standard akademik.

2) Angka putus kuliah/pindah prodi. Semakin sedikit yang putus kuliah atau pindah prodi, semakin baik indikasi proses kegiatan akademik.

c. Indikator Keluaran:

1) IPK (Indeks Prestasi Komulatif). Semakin tinggi IPK lulusan mengindikasikan semakin baik indikasi kegiatan akademik prodi PBA. 
2) Lama Studi: Empat tahun untuk prodi PBA dan maksimum tujuh tahun. Semakin pendek semakin baik.

\section{Standard Mutu Lulusan atau Sarjana Pendidikan Bahasa Arab.}

Bagi PBA, mutu pendidikan yang mengacu pada out put harus menghasilkan seorang lulusan sarjana PBA yang memiliki kemampuan (minimal) yaitu seorang sarjana PBA harus memiliki kemampuan dalam (1) kemahiran berbahasa Arab (istima', kalam, qira'ah, dan kitabah); (2) pengetahuan tentang bahasa Arab dan budaya Arab (nahwu, sharaf, mufradat, balaghah dan lain-lain); dan (3) ketrampilan mengajarkan bahasa Arab (metodologi PBA, strategi pembelajaran PBA, pengembangan bahan ajar PBA, evaluasi PBA dan lain-lain) (Effendy, $2005:$ 1).

Dalam Permendiknas No. 16 Tahun 2007 tentang kualifikasi dan kompetensi lulusan Pendidikan Bahasa Arab (PBA) adalah sarjana yang memiliki kemampuan: Mengenal tingkat dan kemampuan bahasa Arab peserta didik secara mendalam.

1. Menguasai bidang studi bahasa Arab.

2. Menyelenggarakan pembelajaran bahasa Arab yang mendidik.

3. Mengembangkan kemapuan professional guru bahasa Arab secara berkelanjutan.

Selain empat hal di atas Kopertais wilayah IV menambahkan bahwa sarjana PBA harus juga memiliki kemampuan sebagai berikut:

1. Meneliti bidang pendidikan dan pembelajaran bahasa Arab.

2. Terampil memanfaatkan teknologi informasi dan komunikasi dalam PBA.

3. Mengembangkan bahan ajar PBA.

4. Menterjemah Arab-Indonesia dan Indonesia-Arab.

5. Memandu Ibadah Haji dan Umrah.

Kesembilan kemampuan di atas bisa diperinci sebagai berikut:

1. Mengenal tingkat dan kemampuan bahasa Arab peserta didik secara mendalam:

a) Memahami karakteristik dan tingkat kemampuan peserta didik dalam berbahasa Arab.

b) Memahami karakteristik dan tingkat kemampuan peserta didik dalam berbahasa Arab yang membutuhkan penanganan khusus.

c) Memahami peserta didik dalam cara belajar dan kesulitan dalam belajar bahasa Arab.

d) Mampu mengembangkan potensi peserta didik dalam berbahasa Arab.

2. Menguasai bidang studi Bahasa arab

a) Menguasai substansi keilmuan Bahasa Arab

b) Menguasai struktur bahasa Arab (Qawaid al-lughah)

c) Menguasai empat ketrampilan berbahasa Arab (maharah istima', kalam, qira'ah dan kitabah)

d) Mampu melakukan kegiatan untuk pengembangan keilmuan bahasa Arab.

3. Kemampuan menyelenggarakan pembelajaran bahasa Arab yang mendidik.

a) Menguasai teori-teori pemerolehan dan pembelajaran bahasa Arab.

b) Mampu mengembangkan kurikulum pembelajaran bahasa Arab secara kreatif dan inovatif.

c) Mampu merancang pembelajaran bahasa arab

d) Mampu melaksanakan pembelajaran bahasa Arab di laboratorium maupun di sekolah

e) Mampu menilai proses dan hasil pembelajaran bahasa arab.

f) Mampu melakukan kegiatan untuk pengembanagan pembelajaran bahasa Arab

4. Kemampuan mengembangkan kemampuan professional guru bahasa Arab secara berkelanjutan. 
a) Selalu menampilkan diri sebagai pribadi yang mantap, stabil, dewasa, arif dan berwibawa.

b) Selalu menampilkan diri sebagai pribadi yang yang berakhlak mulia dan sebagai teladan bagi peserta didik dan masyarakat

c) Selalu berprilaku sebagai guru bahasa Arab secara professional

d) Mampu mengembangkan diri secara terus menerus sebagai guru bahasa Arab secara professional

e) Mampu menilai kinerja sendiri yang dikaitkan dengan pencapaian tujuan utuh PBA.

f) Mampu meningkatkan kulaitas pembelajaran bahasa Arab melalui penelitian tindakan kelas (PTK)

g) sMampu berkomunikasi dengan berbahasa Arab secara efektif dengan peserta didik, semua guru bahasa Arab, dan masyarakat Arab

h) mampu berkontribusi terhadap pengembangan PBA di tingkat local, regional, nasional dan global.

5. Kemampuan meneliti bidang pendidikan dan pembelajan bahasa Arab

a) Terampil melakukan penelitian pembelajaran bahasa Arab.

b) Terampil melakukan penelitian tindakan kelas pembelajaran bahasa Arab.

6. Terampil memanfaatkan teknologi informasi dan komunikasi dalam PBA.

a) Mampu memanfaatkan teknologi informasi dan komunikasi untuk berkomunikasi dan mengembangkan diri.

b) Mampu menggunakan teknologi dalam proses pembelajaran dan pengajaran bahasa Arab.

7. Kemampuan mengembangkan bahan ajar bahasa Arab

a) Terampil merancang bahan ajar PBA yang efektif dan inovatif.

b) Terampil mengembangkan bahan ajar PBA berbasis IT.

c) Mampu menilai kelayakan bahan ajar PBA yang sudah tersedia.

8. Kemapuan menterjemah Arab-Indonesia dan Indonesia-Arab

a) Mampu menterjemah Arab-Indonesia atau sebaliknya secara tertulis atau lisan baik dalam even-even konferens, seminar, dialog atau kunjungan resmi maupun tidak.

b) Mampu menilai dan mengedit karya terjemahan.

9. Kemampuan menggunakan bahasa Arab pariwisata (ibadah haji atau umrah dan pariwisata)

a) Memahami manasik haji, menguasai bahasa Arab fusha maupun amiyah dan mampu membimbing para jamaah haji dan umrah.

b) Mampu memandu jamaah haji ke tempat-tempat bersejarah, museum, dan lainlain.

c) Mampu memahami jamaah untuk menyelesaikan perselisihan dengan pihakpihak maktab, keamanan, bandara dll.

\section{E. TQM pada prodi Pendidikan Bahasa Arab}

Tjiptono dan Diana (2009 : 14-15) mengatakan bahwa ada empat unsur pokok dalam TQM yaitu pelanggan, respek terhadap setiap orang, manajemen berdasarkan fakta, dan perbaikan berkesinambungan. Unsur pertama adalah pelanggan, baik pelanggan internal maupun eksternal (Nurkhalis, 2003 : 70-71). Pelanggan internal adalah ketua program studi (kaprodi) atau jurusan (kajur), dosen dan staf PBA. Sedangkan pelanggan external adalah mahasiswa PBA (external primer/utama), orang tua dan kepala sekolah yang menerima lulusan PBA di sekolahnya (eksternal sekunder/kedua) dan pasar kerja atau masyarakat luas (eksternal tersie/ketigar). 
Mengadopsi Piramida Terbalik Pendidikan yang digagas oleh Edward Sallis (2005 : 81) dan Piramida Terbalik Pesantren TQM yang dikembangkan oleh Umiarso dan Zazin Nur (2011 : 146), maka bisa dibuat juga Piramida Terbalik PBA TQM. Yaitu piramida yang memberikan implikasi bahwa ketua program studi menjadi pelayan bagi para dosen. Begitu juga para dosen melayani bawahannya, hingga melayani mahasiswa. Sehingga bisa diilustrasikan sebagai berikut:
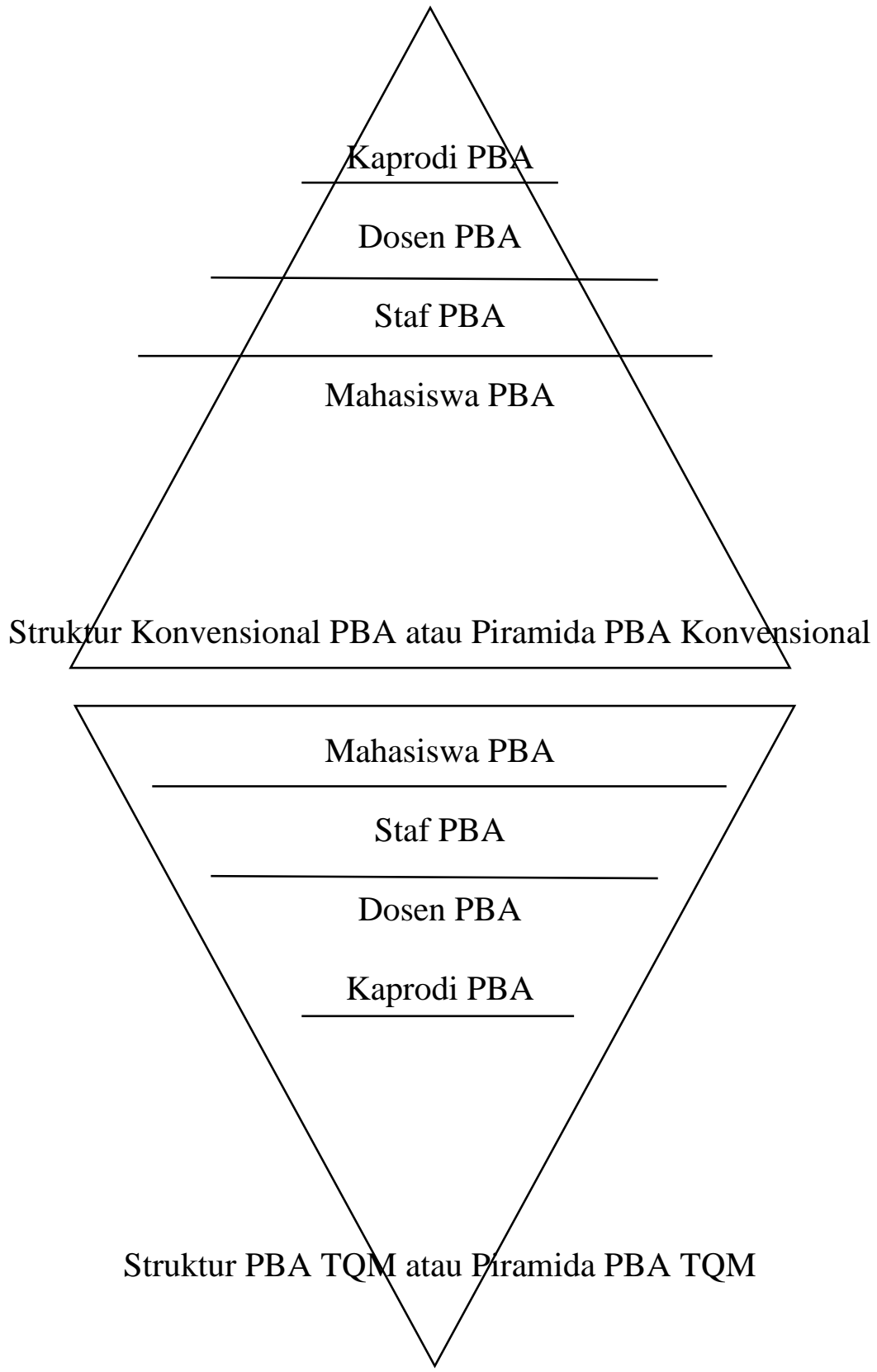

Unsur yang kedua adalah respek terhadap setiap orang. Setiap orang di TQM dipandang sebagai individu yang mempunyai talenta dan kreatifitas tersendiri dan unik. Jadi, setiap orang di program studi PBA dianggap sebagi sumber daya struktur PBA yang bernilai. Karena itu, setiap individu diberi kesempatan untuk mengembangkan diri dan berpartisipasi dalam pengambilan keputusan. Unsur yang ketiga adalah manajemen berdasarkan fakta. Artinya program studi PBA berorientasi pada fakta bukan perasaan (feeling). Dua konsep terkait dengan fakta: (1) prioritisasi (prioritation) yaitu konsep bahwa perbaikan tidak dapat dilakukan pada semua aspek 
pada saat yang bersamaan, mengingat keterbatasan sumber daya yang ada. Dengan demikian, dengan menggunakan data, maka manajemen dan tim dapat memfokuskan usahanya pada sistuasi yang tertentu yang vital; dan (2) variati (variation) atau varaibilitas kinerja manusia. Data dapat dapat memberikan gamabaran mengenaivariabilitas yang merupakan bagian yang wajar dari setiap system organisasi. Dengan demikian manajemen dapat memprediksi hasil dari setiap keputusan atau tindakan yang dilakukan (Zazin Nur, 2011 : 146).

Unsur yang keempat adalah perbaikan berkesinambungan, salah satunya dengan memakai model PDCA (Plan, Do, Check, Action) yang akan menghasilkan pengembangan mutu yang berkelanjutan (continuous improvement) atau kaizen mutu pendidikan tinggi di Perguruan Tinggi. (Depdiknas, 2003 : 13)

\section{Siklus Kendali Mutu}

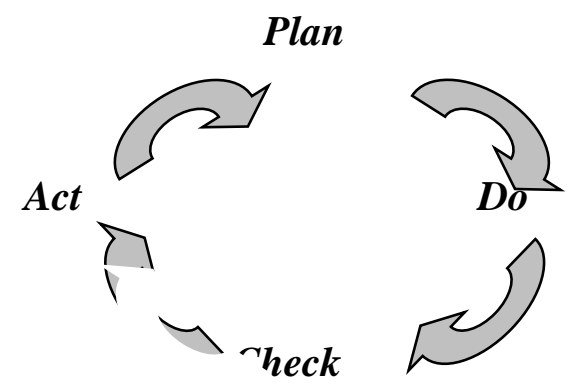

Siklus ini menggambarkan bahwa, mutu harus ditingkatkan secara terusmenerus agar dapat memuaskan stakeholders. Siklus tersebut dapat dijelaskan sebagai berikut:

1. Plan (P): langkah pertama, menentukan masalah yang ada di PBA yang akan di atasi atau kelemahan yang akan diperbaikidan menyusun rencana (solusi) untuk mengatasi masalah itu, yang berarti meningkatkan mutu.

2. Do (D): langkah kedua, melaksanakan rencana pada taraf ujicoba dan memperhatikan semua prosesnya.

3. Check (C): Langkah ketiga, mengamati atau meneliti apa yang telah dilaksanakan dan menemukan kelemahan-kelemahan yang perlu diperbaiki, di samping hal-hal yang sudah benar dilakukan. Berdasarkan kelemahankelemahan itu disusun rencana perbaikan untuk dilaksanakan selanjutnya.

4. Act (A): langkah keempat, melaksanakan keseluruhan rencana peningkatan mutu, termasuk perbaikan kelemahan-kelemahan yang ada di nomer 3 . Hasilnya diamati, dan akan muncul tiga kemungkinan:

(a) Hasilnya bermutu, sehingga cara bersangkutan dapat dipergunakan di masa yang akan datang;

(b) Hasilnya tidak bermutu. Ini berarti cara bersangkutan tidak baik dan harus diganti atau diperbaiki lagi di masa datang.

(c) Cara bersangkutan mungkin dapat dipakai untuk keadan yang berbeda atau keadaan yang lain.

Dengan demikian, proses tidak berhenti pada nomer ke-4 tetapi kembali lagi ke proses pertama. Proses-proses berupa lingkaran demikianlah yang terjadi dalam peningkatan mutu berkelanjutan (continuous quality improvement).

Lebih lanjut, secara operasional, menurut Sallis, mutu dalam TQM ditentukan oleh dua faktor: Pertama, Menyesuaikan diri dengan spesifikasi. Sering disimpulkan 'sesuai dengan tujuan dan manfaat'. Jadi selama produk atau jasa dalam hal ini lulusan atau sarjana PBA sesuai dengan spesifikasi dan standar program studi 
yang telah ditetapkan, maka lulusan PBA tersebut adalah lulusan atau sarjana yang memiliki mutu atau berkukualitas. Pendapat tentang mutu yang demikian sering kali disebut dengan istilah 'mutu sesungguhnya' (quality in fact). Kedua, memuaskan dan melampaui keinginan dan kebutuhan pelanggan. Definisi ini disebut juga dengan istilah 'mutu sesuai persepsi' (quality in perception). Mutu ini juga bisa disebut sebagai mutu yang hanya ada pada di mata orang yang melihatnya.

Dari dua faktor mutu di atas bisa disimpulkan dengan standar mutu sebagai berikut:

1. Standar produk atau jasa (quality in fact)

a) Kesesuain dengan spesifikasi

b) Keseuaian dengan tujuan dan manfaat

c) Tanpa cacat (zero defects)

d) Selalu baik sejak awal

2. Standar Pelanggan (quality in perception)

a) Kepuasan pelanggan

b) Memenuhi kebutuhan pelanggan

c) Menyenangkan pelanggan

Jika melihat paparan di atas, maka jika lulusan atau sarjana PBA sudah memiliki standar-standar mutu di atas, maka lulusan PBA tersebut bisa dikategorikan bermutu atau berkualitas. Meskipun definisi bermutu atau berkualitas menurut masing-masing individu bisa berbeda atau relatif.

Lebih detailnya, jika lulusan PBA mempunyai kompetensi seperti yang sudah dipaparkan sebelumnya di "standar lulusan atau sarjana PBA", sesuai dengan tujuan manfaat prodi PBA, tanpa cacat artinya tidak pernah melakukan kesalahan, dan selalu baik sejak awal mengajar di lembaga atau institusi, maka lulusan PBA tersebut bermutu sesungguhnya (quality in fact). Ditambah lagi jika lulusan PBA tersebut 'memuaskan' stake holder yang merekrutnya seperti kepala madrasah, memenuhi kebutuhan (kepala) madrasah dan menyenangkannya, maka bisa dikatakan lulusan PBA tersebut juga bermutu sesuai persepsi (kepala) madrasah atau siapapun yang mendapatkan jasanya.

\section{F. Penutup}

TQM adalah sebuah pendekatan praktis dan strategis yang memfokuskan diri pada kebutuhan pelanggan. Tujuannya adalah untuk mencari hasil yang lebih baik. TQM merupakan suatu pendekatan sistematis dan hati-hati untuk mencapai tingkatan kualitas yang tepat dengan cara yang konsisten dalam memenuhi kebutuhan dan keinginan pelanggan. Ada empat unsur pokok dalam TQM yang bisa ditemukan dan diterapkan juga pada prodi PBA yaitu: pelanggan, respek terhadap setiap orang, manajemen berdasarkan fakta, dan perbaikan berkesinambungan.

TQM juga mempunyai dua standar mutu yang bisa diimplementasikan pada prodi PBA yaitu (1) standar produk atau jasa (quality in fact), yaitu : kesesuain dengan spesifikasi; keseuaian dengan tujuan dan manfaat; tanpa cacat (zero defects); dan selalu baik sejak awal. (2) standar Pelanggan (quality in perception), yaitu: kepuasan pelanggan; memenuhi kebutuhan pelanggan; dan menyenangkan pelanggan. 


\section{DAFTAR PUSTAKA}

Amtu, Onisimus. 2011. Manajemen Pendidikan di Era Otonomi Daerah: Konsep Strategi dan Implementasi. Bandung: Alfabeta.

Danim, Sudarwan. 2007. Visi Baru Manajemen Sekolah. Jakarta : Bumi Aksara.

Departemen Pendidikan Nasional: Direktorat Jenderal Pendidikan Tinggi. 2003. Pedoman Penjaminan Mutu (Quality Assurance) Pendidikan Tinggi.

Effendy, Fuad. 2005. Metodologi Pengajaran Bahasa Arab. Malang: Misykat.

Kamus Besar Bahasa Indonesia (KBBI). 1991. Jakarta: Depdiknas.

Kuikulum Tingkat satuan Pendidikan Tinggi: Panduan bagi Perguruan Tinggi dalam Pengembangan Kurikulum Program Studi S-1 Pendidikan Bahasa Arab. 2009. Surabaya: Kopertais IV Press.

Mulyasana, Dedy. 2011. Pendidikan Bermutu dan Berdaya Saing. Bandung. Rosdakarya.

Nasution, M. N. 2005. Manajemen Mutu Terpadu (Total Quality Manajement). Bogor: Ghalia Indonesia.

Nurkhalis. 2003. Manajemen Berbasis Sekolah: Teori, Model, dan Aplikasi. Jakarta: Gramedia Widiasarana Indonesia.

Sallis, Edward. 2011. Total Quality Manajement in Education (Manajemen Mutu Terpadu Pendidikan. Cetakan ke-12. Alih bahasa: Riyadi \& Fahrurozi. Yogyakarta: IRCiSoD.

Singgih, M.L \& Rahmayanti. 2008. Faktor-faktor yang mempengaruhi kualitas Pendidikan. Prosiding Seminar Nasional Teknoin. Yogyakarta.

Tjiptono, Fandy dan Diana, Anastasia. 2009. Total Quality Manajement. Yogjakarta. Andi.

Umiarso \& Zazin, Nur. 2011. Pesantren di tengah Arus Mutu Pendidikan. Rasail: Semarang.

Universitas Gadja Mada. 2003. Buku Panduan Jaminan Mutu Pendidikan Tinggi. UGM: Yogyakarta. 